\title{
Implementasi Model Pembelajaran Flipped Classroom dalam Pembelajaran Jarak Jauh untuk Meningkatkan Partisipasi Belajar IPA
}

\author{
Siti Nurkhasanah \\ SMP Negeri 1 Gangga, Kabupaten Lombok Utara - Provinsi NTB \\ Corresponding Author. Email: nurkhasanah27@gmail.com
}

\begin{abstract}
This study aims to describe the implementation of the flipped classroom Article History SMP Negeri 1 Gangga. This research method used descriptive qualitative research. Revised: 11-03-2021 collection technique used observation sheets, documentation, and tests. While the data analysis technique used qualitative and quantitative descriptive analysis. The results of this study indicate an increase in student participation in taking part in distance learning using the Flipped Classroom model, namely 10 people in week 1, Key Words: 15 weeks 2, 22 weeks 3 and 24 people in week 4, while 4 other people join the Flipped Classroom, study. outside the network. Furthermore, with regard to student responses, it shows Distance Learning, learning model as many as $50 \%$ of students are not happy, as many as $31 \%$ of students are not happy, and $17 \%$ of students are quite happy with distance learning. However, after using the Flipped Classroom learning model, 25\% of students were unhappy, $25 \%$ of students were less than happy, $35 \%$ of students were happy, and $14 \%$ were very happy with distance learning.
\end{abstract} learning model in distance learning to increase participation in science learning at Received: 26-02-2021 The subjects in this study were class IX.2 as many as 28 people. This research data Published: 04-04-2021 that before the implementation of distance learning using the Flipped Classroom Learning Participation.

\begin{abstract}
Abstrak: Penelitian ini bertujuan untuk mendeskripsikan implementasi model pembelajaran flipped classroom dalam pembelajaran jarak jauh untuk meningkatkan partisipasi belajar IPA di SMP Negeri 1 Gangga. Metode penelitian ini menggunakan penelitian deskriptif kualitatif. Subyek dalam penelitian ini adalah kelas IX.2 sebanyak 28 orang. Teknik pengumpulan data penelitian ini menggunakan lembar observasi, dokumentasi, dan tes. Sedangkan teknik analisis datanya menggunakan analisis deskriptif kualitatif dan kuantitatif. Hasil penelitian ini menunjukkan peningkatan partisipasi belajar siswa dalam mengikuti pembelajaran jarak jauh dengan penggunaan model Flipped Classroom, yakni pada minggu 1 sebanyak 10 orang, minggu 2 sebanyak 15, minggu 3 sebanyak 22 dan minggu 4 sebanyak 24 orang, sementara itu 4 orang lainnya mengikuti belajar secara luar jaringan. Selanjutnya, berkaitan dengan respon siswa menunjukkan bahwa sebelum pelaksanaan pembelajaran jarak jauh menggunakan model pembelajaran Flipped Classroom sebanyak 50\% siswa tidak senang, sebanyak $31 \%$ siswa kurang senang, dan $17 \%$ siswa cukup senang dengan pembelajaran jarak jauh. Namun, setelah menggunakan model pembelajaran Flipped Classroom sebanyak 25\% siswa tidak senang, 25\% siswa kurang senang, 35\% siswa senang, dan $14 \%$ sangat senang dengan pembelajaran jarak jauh.
\end{abstract}

How to Cite: Nurkhasanah, S. (2021). Implementasi Model Pembelajaran Flipped Classroom dalam Pembelajaran Jarak Jauh untuk Meningkatkan Partisipasi Belajar IPA. Jurnal Paedagogy, 8(2). doi:https://doi.org/10.33394/jp.v8i2.3532

https://doi.org/10.33394/jp.v8i2.3532

Sejarah Artikel

Diterima: 26-02-2021

Direvisi: 11-03-2021

Diterbitkan: 04-04-2021

\section{Kata Kunci:}

Flipped Classroom, Pembelajaran Jarak Jauh, Partisipasi Belajar.

\section{Pendahuluan}

Awal tahun 2020 ini seluruh dunia dihadapkan pada masalah yang sama yaitu pandemi global Covid-19. Virus Corona atau severe acute respiratory syndrome coronavirus 2 (SARS-CoV-2) adalah virus yang menyerang system pernapasan. Virus Corona bisa menyebabkan gangguan pada system pernapasan, pneumonia akut, sampai kematian. Virus 
ini bisa menyerang siapa saja, baik bayi, anak-anak, orang dewasa, lansia, ibu hamil, maupun ibu menyusui. Virus ini menular dengan cepat dan telah menyebar kewilayah lain di berbagai negara, termasuk Indonesia. Merebaknya kasus penyebaran virus Corona atau Covid-19 sangat berdampak terhadap proses pembelajaran di seluruh wilayah Indonesia tidak terkecuali di Kabupaten Lombok Utara.

Dengan adanya kebijakan yang ditetapkan oleh daerah, maka sekolah harus tetap melaksanakan pembelajaran meskipun dengan jarak jauh (PJJ). Tujuannya antara lain; 1) siswa tetap mendapat haknya untuk belajar, 2) siswa tidak kehilangan waktunya untuk belajar, 3) siswa tetap memperoleh ilmu yang seharusnya dia peroleh. Belajar dari Rumah (BDR) dilaksanakan dengan sistem Pembelajaran Jarak Jauh (PJJ). Dalam Undang-undang No. 20 tahun 2003 pasal 1 ayat 15, dijelaskan bahwa PJJ adalah pendidikan yang peserta didiknya terpisah dari pendidik dan pembelajarannya menggunakan berbagai sumber belajar melalui teknologi komunikasi, informasi dan media lain. Dalam pelaksanaannya, PJJ dibagi menjadi dua pendekatan, yaitu pembelajaran jarak jauh dalam jaringan (daring) dan pembelajaran jarak jauh luar jaringan (luring). Menurut Asmuni (2020), Ahmad (2020), Nurhayati (2020), dan Zaenab (2021) menjelaskan bahwa, dalam pelaksanaan PJJ, satuan pendidikan dapat memilih pendekatan (daring atau luring atau kombinasi keduanya) sesuai dengan karakteristik dan ketersediaan, kesiapan sarana dan prasarana . Mempertimbangkan beberapa hal diantaranya masih ada sebagian siswa belum memiliki HP dan sebagian besar siswa yang ada di daerah yang sulit mendapatkan sinyal internet. Maka Belajar dari rumah (BDR) di SMP Negeri 1 Gangga menggunakan metode daring (dalam jaringan) dan luring (luar jaringan). Ada dua kelompok siswa yaitu siswa yang memiliki HP dan jaringan internet belajar secara daring melalui Google classroom dan group telegram sedangkan siswa yang tidak memiliki HP dan di luar jangkauan internet dilakukan belajar secara luring yakni dibuat kelompok perdusun dan diberikan kunjungan oleh guru secara terjadwal. Pada penelitian ini hanya akan membahas belajar secara daring.

Pembelajaran IPA yang sebaiknya dilaksanakan di laboratorium atau lebih banyak praktikum, menjadi sebuah tantangan yang ditemukan di lapangan. Tentu saja yang paling utama adalah sarana pembelajaran jarak jauh yang dikenal dengan daring (dalam jaringan). Pembelajaran jarak jauh, pada dasarnya telah dimulai pada semester dua tahun pelajaran 2019/2020, namun dikarenakan belum adanya pengalaman dan program yang terencana dengan baik maka PJJ yang dilaksanakan belum berhasil disebabkan antara lain: tidak adanya control bagi siswa yang tidak mengikuti PJJ secara daring, siswa yang belum terbiasa dengan pola belajar jarak jauh sehingga mengakibatkan partisipasi dan keaktifan rendah, tingkat kebosanan siswa yang tinggi karena belajar dianggap monoton dari tugas ke tugas.

Berdasarkan masalah tersebut, perlu dilakukan pembenahan dalam proses pembelajaran di masa pandemi Covid-19 melalui tindakan model yang tepat dan dapat digunakan dalam pembelajaran IPA secara daring. Disamping itu juga, menurut Sadikin \& Hamidah (2020), Susmiati (2020), dan Zaenab (2021), menjelaskan bahwa guru harus melakukan variasi dalam menyampaikan informasi pembelajaran kepada peserta didik sehingga peserta jadi termotivasi dan aktif dalam mengikuti kegiatan pembelajaran secara daring. Model pembelajaran flipped classroom merupakan salah satu model pembelajaran yang cocok pada masa BDR ini. Flipped classroom adalah strategi pembelajaran campuran yang membalikkan model pengajaran dan pembelajaran di dunia pendidikan secara tradisional (Cortese, Wals dan Jickling dalam Usmadi dan Ergusni, 2019). Sedangkan Bishop dan Verleger dalam Usmadi dan Ergusni (2019) mendefinisikan strategi Flipped Classroom sebagai kegiatan pembelajaran kelompok interaktif di dalam kelas, dan mengarahkan 
instruksi individu berbasis komputer, misal Video ceramah, di luar kelas. Menurut Fulton, Roehl et al., dalam Usmadi dan Ergusni (2019) banyak hasil penelitian telah menemukan bahwa pembelajaran dengan penerapan strategi Flipped Classroom dapat memberikan sejumlah keuntungan bagi guru dan peserta didik. Misalnya, menggunakan strategi pembelajaran aktif di kelas memungkinkan guru untuk memahami gaya dan kesulitan belajar peserta didik yang lebih baik; untuk menggunakan waktu kelas lebih efektif dan kreatif; dan untuk memenuhi kebutuhan pembelajaran kelompok peserta didik yang beragam sesuai dengan kurikulum dan memberikan bimbingan guru ke peserta didik yang dipersonalisasi dan kolaborasi antar rekan. Begitupula, Brent dalam Usmadi dan Ergusni, 2019) mendefenisikan strategi Flipped Classroom sebagai pendekatan yang dapat diberikan oleh pendidik dengan cara meminimalkan jumlah instruksi langsung dalam praktek mengajar mereka sambil memaksimalkan interaksi antar peserta didik. Strategi Flipped Classroom ini memanfaatkan teknologi yang mendukung materi pembelajaran bagi peserta didik yang dapat di akses secara online. Pada pendekatan ini bahan pelajaran harus dipelajari oleh peserta didik di rumah sebelum pembelajaran. Pendidik sewaktu di dalam kelas tidak menjelaskan materi secara detail, tetapi hanya mereviu video yang sudah diberikan. Selanjutnya pendidik memberikan lembar diskusi kelompok (LDK).

Strategi Flipped Classroom dapat diterap kan di kelas dengan langkah-langkah: (1) Sebelum tatap muka, peserta didik diminta untuk belajar mandiri di rumah mengenai materi pertemuan berikutnya, dengan menonton video pembelajaran. (2) Pada pembelajaran di kelas, peserta didik dibagi menjadi beberapa kelompok yang terdiri dari 4 atau 5 orang perkelompok. (3) Peran pendidik pada saat pembelajaran berlangsung adalah memfasilitasi berlangsungnya diskusi atau sebagai fasilitator. (4) Pendidik memberikan kuis atau tes untuk mengukur pemahaman peserta didik terhadap materi pembelajaran. Dari beberapa definisi, dapat disimpulkan bahwa Flipped Classroom merupakan pembelajaran dengan kelas terbalik. Dikaitkan dengan pembelajaran jarak jauh, dimana tidak ada tatap muka maka model pembelajaran Flipped Classroom, peneliti modifikasi yakni siswa mempelajari materi pelajaran di rumah (melalui menonton video pembelajaran, membuat rangkuman, mencatat poin-poin penting, membuat pertanyaan, diskusi dengan teman secara online, atau membaca sumber-sumber yang dibutuhkan). Di dalam kelas maya yaitu melalui telegram dilakukan diskusi, presentasi, penjelasan terhadap konsep-konsep yang belum dipahami siswa, tetapi ini sifatnya untuk penguatan atau pendalaman. Sementara itu google classroom digunakan untuk input materi berupa modul dan LKS, tugas secara tertulis di kumpulkan melalui google classroom sementara tugas yang harus di diskusikan atau presentasikan melalui kelas telegram.

Adapun tujuan penelitian ini adalah untuk mendeskripsikan implementasi model pembelajaran flipped classroom dalam pembelajaran jarak jauh untuk meningkatkan partisipasi belajar IPA di SMP Negeri 1 Gangga.

\section{Metode Penelitian}

Metode penelitian ini menggunakan penelitian deskriptif kualitatif yaitu menggambarkan peristiwa yang terjadi saat melakukan kegiatan pembelajaran daring. Subyek dalam penelitian ini adalah kelas IX.2 sebanyak 28 orang. Pelaksanaan kegiatan daring dilakukan 4 kali pertemuan atau 12 jam pelajaran dengan alokasi waktu 12 x 30 menit (selama 4 minggu) secara daring melalui Google classroom serta group Telegram.Tahapantahapan dalam penelitian ini adalah sebagai berikut: 


\section{Tahap Perencanaan}

1) Sosialisasi kepada siswa untuk memasang aplikasi Google classroom dan telegram pada HP siswa atau di laptop (bagi yang memiliki).

2) Membuat kelas Google untuk tiap kelas

3) Membuat group telegram untuk tiap kelas

4) Guru sebagai penulis membuat rencana persiapan pembelajaran untuk empat kali pertemuan dan tugas mandiri siswa termasuk lembar pengamatan keaktifan siswa.

5) Menyiapkan bahan tayang berupa penguatan materi ajar

6) Menyediakan lembar instrumen berupa kuisioner angket diagnosis pembelajaran melalui google form

7) Mengirimkan Materi pembelajaran dalam bentuk modul dan video serta penugasan melalui Google classroom.

8) Melakukan diskusi dan presentasi melalui kelas telegram sesuai jadwal pelajaran yang telah ditetapkan.

\section{Tahap Pelaksanaan Kegiatan}

1) Sosialisasi kepada siswa untuk memasang aplikasi Google classroom dan telegram pada HP siswa dengan cara :

a) Menggunakan protocol kesehatan, mengumpulkan siswa secara bertahap untuk mendapatkan sosialisasi pelaksanaan BDR, siswa diminta membawa HP

b) Siswa dipandu untuk memasang aplikasi Google Classroom dan bergabung dengan kelas yang sudah dibuat oleh sekolah (Tim BDR)

c) siswa dibimbing cara membuka, membaca tugas dan mengirimkan tugas melalui Google classroom

d) siswa dipandu memasang aplikasi telegram dan masuk ke dalam kelas telegram yang sudah disiapkan oleh Tim BDR

2) Memberikan sosialisasi pada siswa bahwa materi dan penugasan dilakukan melalui Google Classroom.

3) Diskusi tentang kesulitan materi dan penugasan dilakukan sesuai jadwal mata pelajaran yang telah dibuat. Diskusi ini berlangsung di kelas telegram. Dalam kelas telegram ini, dilakukan layaknya kita ada dalam kelas. Guru membuka pelajaran dengan mengucapkan salam dan menanyakan kabar peserta didik. Kegiatan inti dengan meminta siswa untuk mengungkapkan tugas dan masalah yang dihadapi dalam menyelesaikan tugas. Kegiatn penutup dilakukan di akhir pembelajaran, guru memberikan rangkuman dan member reward berupa bintang kepada siswa yang aktif belajar di kelas telegram

4) Apabila siswa memerlukan komunikasi dengan guru atau temannya di luar jadwal pelajaran dapat dilakukan setiap saat menggunakan WA group.

\section{Tahap Observasi}

Pada tahap ini dilaksanakan saat pemberian tindakan yakni :

1) Observasi yang dilakukan guru berdasarkan partisipasi siswa selama melakukan diskusi. Semua kejadian dicatat oleh guru sebagai penulis dengan format observasi yang telah disusun.

2) Hal-hal yang menjadi perhatian guru sebagai penulis dalam tahap ini adalah partisipasi siswa selama proses belajar berlangsung antara lain siswa yang hadir pada saat pembelajaran, siswa yang memberikan jawaban sementara ketika diberikan masalah di awal pembelajaran,siswa yang memperhatikan materi yang diajarkan guru.

3) Guru sebagai penulis memberikan penguatan materi di akhir pertemuan.

4) Guru memberikan tugas mandiri yang dikirim melalui Google Classroom selanjutnya 
siswa mengirimkan jawaban masing-masing melalui untuk memperoleh umpan balik.

5) Seperti yang dijelaskan sebelumnya, bahwa aplikasi yang digunakan adalah Google Classroom dan Telegram kelas. Sedangkan instrumen yang digunakan adalah :

a) Instrumen untuk mengamati proses pembelajaran

b) Instrumen kuisioner diagnosis awal dan diagnosis akhir

c) Instrumen tes kemampuan kognitif berupa soal-soal sederhana untuk didiskusikan selama pembelajaran berlangsung.

Adapun teknik analisis data yang digunakan dalam penelitian ini adalah analisis deskriptif kualitatif dan kuantitatif.

\section{Hasil Penelitian dan Pembahasan}

Dari hasil penelitian yang dilakukan pada siswa kelas IX.2 dengan pengisian kousioner diagnosis awal, diagnosis akhir serta lembar pengamatan keaktifan siswa yang diisi oleh teman sejawat selama pelaksanaan PJJ tahun pelajaran 2020/2021 dapat diuraikan sebagai berikut :

1) Proses pembelajaran jarak jauh menggunakan model pembelajaran Flipped Classroom pada kelas IX.2 menunjukkan adanya peningkatan partisipasi siswa dalam mengikuti kegiatan pembelajaran yang berlangsung secara daring.

2) Proses pembelajaran jarak jauh menggunakan model pembelajaran Flipped Classroom pada kelas IX.2 memperoleh apreasi yang tinggi berdasarkan hasil tes diagnostic awal dan akhir.

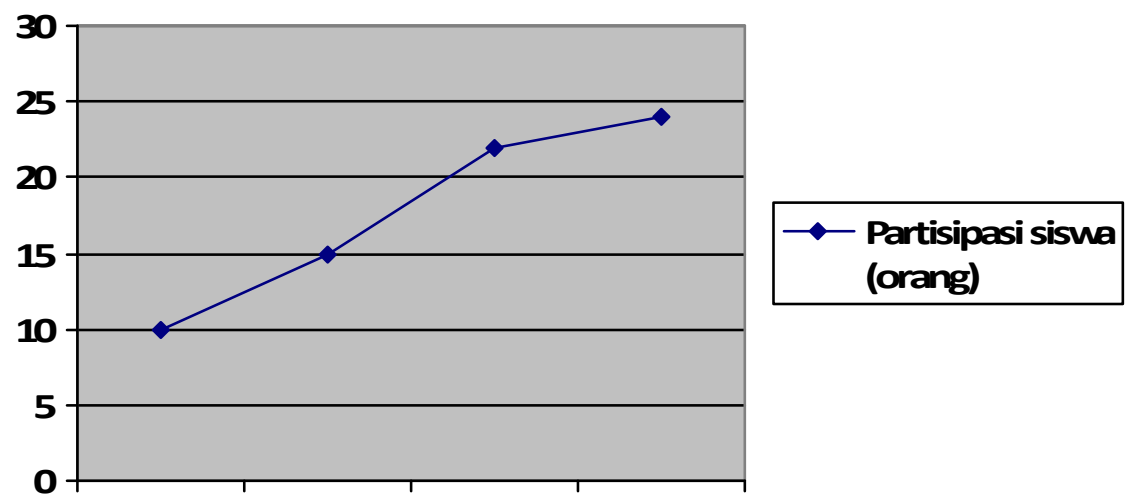

Mnggu 1 Minggu 2 Minggu 3 Minggu 4

Gambar 1. Grafik Prosentase Peningkatan Partisipasi Siswa dalam Mengikuti Kegiatan Pembelajaran Secara Daring Menggunakan Model Pembelajaran Flipped Classroom

Tabel 1. Diagram Lingkaran yang Menggambarkan Respon Siswa selama pelaksanaan PJJ menggunakan Model Pembelajaran Flipped Classroom melalui Tes Diagnostik Awal dan Akhir

\begin{tabular}{|c|c|c|c|}
\hline No & Uraian & Tes Diagnostik Awal & Tes Diagnostik Akhir \\
\hline 1 & $\begin{array}{c}\text { Perasaan Belajar } \\
\text { secara jarak jauh }\end{array}$ &
\end{tabular}




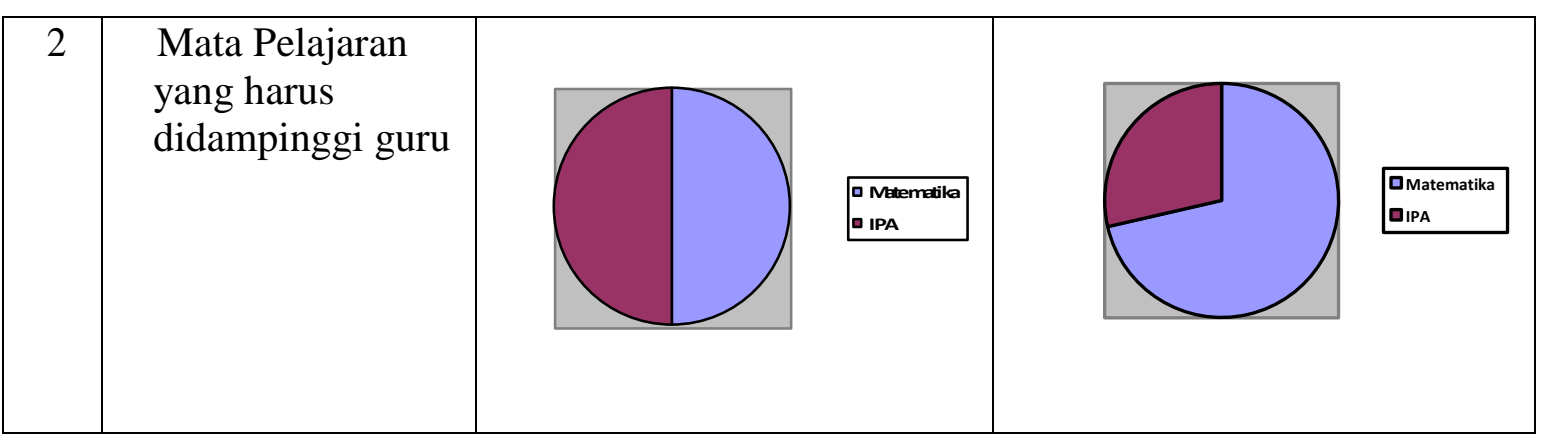

Berdasarkan hasil pada gambar 1 diatas, grafik peningkatan partisipasi siswa dalam mengikuti PJJ dengan penggunaan model Flipped Classroom menunjukkan adanya peningkatan yang signifikan, dimana pada minggu 1 sebanyak 10 orang, minggu 2 sebanyak 15, minggu 3 sebanyak 22 dan minggu 4 sebanyak 24 orang, sementara itu 4 orang lainnya mengikuti belajar secara luring. Hal ini menunjukkan bahwa dengan adanya pembelajaran terbalik, dimana siswa belajar dan praktek di rumah kemudian dipresentasikan melalui kelas telegram membuat siswa menjadi tertarik untuk mengikuti pembelajaran.

Selanjutnya pada gambar 2, diagram respon siswa memperlihatkan bahwa sebelum pelaksanaan PJJ menggunakan Model Pembelajaran Flipped Classroom menunjukkan sebanyak 50\% siswa tidak senang PJJ, sebanyak 31\% siswa kurang senang dengan PJJ dan 17\% siswa cukup senang dengan PJJ. Namun setelah PJJ menggunakan Model Pembelajaran Flipped Classroom sebanyak 25\% siswa tidak senang dengan PJJ, 25\% siswa kurang senang dengan PJJ, 35\% siswa senang dengan PJJ dan 14\% sangat senang dengan PJJ. Adanya peningkatan pada siswa yang senang dan sangat senang dengan PJJ.

Sementara itu, pada jenis mata pelajaran apakah harus didampingi guru, sebelum pelaksanaan PJJ menggunakan Model Pembelajaran Flipped Classroom menunjukkan sebanyak $50 \%$ menganggap IPA harus didampingi guru dan 50\% lagi Matematika harus didampingi guru. Selanjutnya setelah pelaksanaan PJJ menggunakan Model Pembelajaran Flipped Classroom menunjukkan sebanyak $71 \%$ menyatakan Matematika harus didampingi guru, sedangkan IPA $29 \%$ perlu didampingi guru, artinya bahwa $71 \%$ siswa dapat belajar IPA secara daring dan secara mandiri.

Penelitian sebelumnya mengenai Model Pembelajaran Flipped Classroom dilakukan oleh Yuniarsih, Eky Kusuma Hapsari, Muhamad Zakaria (2020) di Fakultas Bahasa dan Seni, Universitas Negeri Jakarta menyatakan bahwa penerapan blended learning model flipped classroom efektif, namun bagi peserta didik tertentu hal ini menjadi beban karena harus banyak meluangkan waktu belajar mandiri di luar kelas, apalagi ketika banyak tugas dari mata kuliah yang lain (lihat diagram 1). Selain itu, materi tidak begitu paham karena tidak ada penjelasan secara langsung dari pengajar. Sehingga perlu adanya koordinasi dengan pengajar yang lain untuk menentukan jenis tugas yang akan diberikan. Penelitian serupa juga dilakukan oleh Sinmas, Wolfharda Fitriani, Chandra Sundaygara, dan Kurriawan Budi Pranata (2019) di SMK Negeri 2 Singosari dengan judul "Pengaruh PBL Berbasis Flipped Class terhadap Prestasi ditinjau dari Motivasi Belajar Siswa. Hasil penelitian ini menunjukan bahwa (1) ada perbedaan prestasi belajar siswa yang belajar melalui model pembelajaran problem based learning berbasis flipped class dengan siswa yang belajar melalui model pembelajaran konvensional, (2) ada perbedaan prestasi belajar antara siswa yang memiliki motivasi belajar tinggi dengan siswa yang memiliki motivasi belajar rendah, (3) terdapat interaksi antara model pembelajaran problem based learning berbasis flipped class dengan motivasi terhadap prestasi belajar siswa. 


\section{Kesimpulan}

Kesimpulan yang diperoleh dari hasil penelitian ini bahwa pembelajaran jarak jauh yang dilaksanakan selama pandemi Covid-19 menggunakan model pembelajaran Flipped Classroom pada kelas IX.2 SMPN 1 Gangga tahun pelajaran 2020/2021 dapat berjalan baik, dapat meningkatkan partisipasi siswa untuk mengikuti pembelajaran jarak jauh secara daring, semakin banyak siswa yang senang dengan PJJ dan dapat belajar IPA secara daring.

\section{Saran}

Adapun saran yang dapat disampaikan berdasarkan hasil penelitian ini antara lain agar guru atau pendidik lainnya dapat menerapkan model pembelajaran Flipped Classroom sebagai salah satu solusi untuk meningkatkan partisipasi siswa dalam pembelajaran jarak jauh secara daring (dalam jaringan) maupun secara luring (luar jaringan).

\section{Daftar Pustaka}

Ahmad, A. (2020). Peningkatan Kompetensi Pedagogik Guru dalam Pembelajaran Jarak Jauh Melalui Pendampingan Sistem Daring, Luring, atau Kombinasi pada Masa New Normal Covid-19. Jurnal Paedagogy, $\quad 7(4), \quad 258-264$. doi:https://doi.org/10.33394/jp.v7i4.2803

Asmuni, A. (2020). Problematika Pembelajaran Daring di Masa Pandemi Covid-19 dan Solusi Pemecahannya. Jurnal Paedagogy, 7(4), 281-288. doi:https://doi.org/10.33394/jp.v7i4.2941

Kurniawati, Meyla, Harja Santanapurba, and Elli Kusumawati. (2019). "Penerapan Blended Learning Menggunakan Model Flipped Classroom berbantuan Google Classroom dalam Pembelajaran Matematika SMP." EDU-MAT: Jurnal Pendidikan Matematika 7.1

Maolidah, Irna Septiani, Toto Ruhimat, and Laksmi Dewi. (2017). "Efektivitas penerapan model pembelajaran flipped classroom pada peningkatan kemampuan berpikir kritis siswa." Educational Technologia 1.2.

Mirlanda, Ela Priastuti, Hepsi Nindiasari, and Syamsuri Syamsuri. (2019). "Pengaruh Pembelajaran Flipped Classroom Terhadap Kemandirian Belajar Siswa Ditinjau Dari Gaya Kognitif Siswa." Symmetry: Pasundan Journal of Research in Mathematics Learning and Education 4.1: 38-49.

Nurhayati, E. (2020). Meningkatkan Keaktifan Siswa Dalam Pembelajaran Daring Melalui Media Game Edukasi Quiziz pada Masa Pencegahan Penyebaran Covid-19. Jurnal Paedagogy, 7(3), 145-150. doi:https://doi.org/10.33394/jp.v7i3.2645

Rusdi, Dian Evriyani, dan Dwi Khaerunnisa Praharsih. (2016). "Pengaruh model pembelajaran peer instruction flip dan flipped classroom terhadap hasil belajar kognitif siswa pada materi sistem ekskresi." Biosfer: Jurnal Pendidikan Biologi 9.1: $15-19$.

Sadikin, A., \& Hamidah, A. (2020). Pembelajaran Daring di Tengah Wabah Covid-19. Biodik, 6(2), 109-119. https://doi.org/10.22437/bio.v6i2.9759

Sinmas, Wolfharda Fitriani, Chandra Sundaygara, and Kurriawan Budi Pranata. (2019). "Pengaruh PBL Berbasis Flipped Class terhadap Prestasi ditinjau dari Motivasi Belajar Siswa." RAINSTEK: Jurnal Terapan Sains \& Teknologi 1.3: 14-20.

Siti Husnul Bariah, Dian Rahadian, Iwan Putra Tresna M. (2019). Implementasi E-learning Dengan Model Flipped Classroom Dalam Aktivitas Belajar Siswa Pada Mata Pelajaran SistemKomputer. Jurnal PETIK Volume 5, Nomor 2, September 2019. 
Subagia, I. Made. (2017). "Penerapan model pembelajaran flipped classroom untuk meningkatkan prestasi belajar ipa siswa kelas x ap 5 smk negeri 1 amalapura i. Pendahuluan tahun ajaran 2016/2017." Lampuhyang 8.2: 14-25.

Susmiati, E. (2020). Meningkatkan Motivasi Belajar Bahasa Indonesia Melalui Penerapan Model Discovery Learning dan Media Video Dalam Kondisi Pandemi Covid-19 bagi Siswa SMPN 2 Gangga. Jurnal Paedagogy, 7(3), 210-215. doi:https://doi.org/10.33394/jp.v7i3.2732

Usmadi, Ergusni. (2019). Penerapan Strategi Flipped Classroom dengan Pendekatan Scientific dalam Pembelajaran Matematika pada Kelas XI SMKN 2 Padang Panjang. Jurnal Eksata Pendidikan (JEP). Doi: https://doi.org/10.24036/jep/vol3-iss1/333

Yuniarsih, Eky Kusuma Hapsari, Muhamad Zakaria. (2020). Penggunaan Blended earning Model Flipped Classroom Terhadap Pelajaran Kaiwa III. Jurnal Kata : Penelitian tentang Ilmu Bahasa dan Sastra Special Issue 2020 E-ISSN: 2502-0706: http://ejournal.kopertis10.or.id/index.php/kata

Zaenab, Z. (2021). Kolaborasi Zoom dengan WAG Sebagai Potret Merdeka Belajar pada Masa New Normal di SMK Negeri 4 Gowa. Jurnal Paedagogy, 8(1), 24-30. doi:https://doi.org/10.33394/jp.v8i1.3129

Zubaidah, Siti dkk. (2018). Buku Guru Ilmu Pengetahuan Alam SMP/MTs Kelas IX. Jakarta: Pusat Kurikulum dan Perbukuan, Balitbang, Kemendikbud. 